\title{
Effect of Benzotriazole on the Localized Corrosion of Copper Covered with Carbonaceous Residue
}

\author{
Yun-Ho Lee $\mathbb{1}$, Min-Sung Hong, Sang-Jin Ko and Jung-Gu Kim*
}

Citation: Lee, Y.-H.; Hong, M.-S.; Ko, S.-J.; Kim, J.-G. Effect of Benzotriazole on the Localized Corrosion of Copper Covered with Carbonaceous Residue. Materials 2021, 14, 2722. https:// doi.org/10.3390/ma14112722

Academic Editor: Bożena Łosiewicz

Received: 29 April 2021

Accepted: 19 May 2021

Published: 21 May 2021

Publisher's Note: MDPI stays neutral with regard to jurisdictional claims in published maps and institutional affiliations.

Copyright: (c) 2021 by the authors. Licensee MDPI, Basel, Switzerland. This article is an open access article distributed under the terms and conditions of the Creative Commons Attribution (CC BY) license (https:// creativecommons.org/licenses/by/ $4.0 /)$.
School of Advanced Materials Science and Engineering, Sungkyunkwan University (SKKU), Suwon 16419, Korea; yunho0228@naver.com (Y.-H.L.); smith803@naver.com (M.-S.H.); tkdwls1315@naver.com (S.-J.K.)

* Correspondence: kimjg@skku.edu; Tel.: +82-31-290-7360

\begin{abstract}
Carbonaceous residues on copper pipes during the manufacturing process are known to be one of the main causes of pitting corrosion on copper pipes. This study examined the corrosioninhibiting effect of benzotriazole (BTA) on C12200 copper pipes with carbonaceous film in synthetic tap water. In the absence of BTA, localized corrosion mechanisms due to galvanic corrosion, crevice corrosion, and oxygen-concentration cell were proposed in the boundary part of the carbonaceous film on the copper through X-ray photoelectron spectroscopy (XPS), scanning electron microscopy (SEM) with energy dispersive spectrometer (EDS) analyses. Electrochemical tests showed that BTA inhibits corrosion by forming $\mathrm{Cu}-\mathrm{BTA}$ complexes on all over the copper surface where carbonaceous film is present. BTA mitigates galvanic corrosion and crevice corrosion at the boundary of the carbonaceous film and suppresses the formation of oxygen-concentration cells through the formation of a $\mathrm{Cu}-\mathrm{BTA}$ complex.
\end{abstract}

Keywords: copper corrosion; localized corrosion; BTA inhibitor; inhibition; carbonaceous residue

\section{Introduction}

Copper has excellent corrosion resistance and has been widely used for the tube of pipe-borne water. More than $80 \%$ of all water pipes in Europe and North America are made of copper [1]. However, despite the excellent corrosion resistance of copper, leakage problems due to pitting corrosion occur constantly. Extensive research has been conducted in this regard in recent years. Many research papers have been reported, including excess carbonaceous manufacturing residues on pipe surfaces, soldering flux, water chemistry, microbial activity, and other variables within a given water distribution system [2-6].

The most widely used method for preventing copper corrosion is the addition of corrosion inhibitors. Benzotriazole (BTA) is one of the most effective corrosion inhibitors for copper, and many studies have been conducted on BTA. Figure 1 shows the chemical structure of BTA. When copper is immersed in a solution containing BTA, it is believed that BTA forms a protective layer in the solutions [7]. The corrosion-inhibiting mechanism of BTA is generally accepted as the formation of a protective layer on the Cu surface by the formation of a $\mathrm{Cu}-\mathrm{BTA}$ complex by a $\mathrm{Cu}-\mathrm{N}$ bonds in BTA [8,9]. Although there is controversy regarding BTA inhibiting mechanisms, many researchers have studied BTA as an effective inhibitor for different conditions. Walker showed that inhibiting efficiency (IE\%) was $100 \%$ when $1 \mathrm{mM}$ BTA was added under dilute seawater solution, dilute $\mathrm{NaNO}_{2}$ solution, and dilute $\mathrm{NaCl}$ solution conditions [10]. Musiani showed that BTA was less effective at a low $\mathrm{pH}$ level [11]. P. Yu researched the inhibition efficiency of BTA on copper in deionized water. When BTA concentration exceeded $8 \mathrm{ppm}$ in deionized water, IE\% exceeded 80\% [12]. Ross and Berry investigated BTA inhibitory effectiveness under 10\% $\mathrm{H}_{2} \mathrm{SO}_{4}$, low or high flow rate solution [13]. In addition, many studies on the inhibition efficiency of BTA under various conditions were conducted $[7,9,14-16]$. 


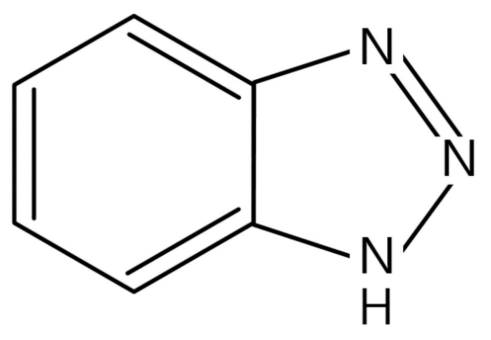

Figure 1. Molecular structure of benzotriazole.

However, most of the experimental conditions mentioned above are different from the actual pipe conditions in use because these experiments were performed on a polished copper surface. Copper pipes used in fields contain carbonaceous residues from the manufacturing process. Carbonaceous residues are produced by the oxidation of the drawing oil on the copper surface during pipe drawing and soft annealing. Carbonaceous residues are known to be the major cause of pitting corrosion of copper pipes $[2,17,18]$. To prevent this type of corrosion, the UK and other European countries provided a standard specification on the amount of carbon content on pipe surfaces after cleaning copper pipes during the manufacturing process [19]. However, in most countries, such as the Republic of Korea, that do not have a standard specification, carbonaceous residues are found on copper pipes after the manufacturing process. In recent years, corrosion due to carbonaceous residues has been identified as a serious problem. A large amount of pitting corrosion occurred within 3-4 years after use in the sprinkler copper tube. As a result of analysis of the leaking tube, it was confirmed that carbonaceous residues were continuously distributed in a thickness of 20-30 $\mu \mathrm{m}$ [20]. Therefore, to accurately validate the effectiveness of BTA to inhibit corrosion in actual copper pipes, it is necessary to study the effect of BTA on copper with carbonaceous residues.

This study discusses performance of BTA as corrosion inhibitor on carbonaceous film-coated copper in synthetic tap water. Scanning electron microscopy (SEM) with energy dispersive spectroscopy (EDS) was used to observe the carbonaceous film-coated copper surfaces. The electrochemical properties of BTA on the carbonaceous film on the copper surfaces were evaluated using a potentiodynamic polarization test and electrochemical impedance spectroscopy (EIS) test. After immersion in an aqueous solution with and without BTA, X-ray photoelectron spectroscopy (XPS) was used to observe the adsorption of BTA on the carbonaceous film-coated copper surface. A potentiostatic polarization test was conducted to confirm the actual corrosion behavior of carbonaceous film-coated copper in the presence or absence of BTA, and then analysis was performed using SEM and EDS.

\section{Materials and Methods}

\subsection{Specimens and Solutions Preparation}

C12200 copper was used in all electrochemical experiments, and the chemical compositions are given in Table 1.

Table 1. Chemical composition of C12200 copper (wt.\%).

\begin{tabular}{cc}
\hline Elements & Composition \\
\hline Copper & 99.9 \\
Phosphorus & $0.015-0.04$ \\
Carbon & 0004 \\
Silicon & 0.01 \\
Fe & 0.01 \\
\hline
\end{tabular}

To clarify the effect of carbonaceous residues on copper, two specimens were used: a polished copper specimen (Specimen 1), and half-coated copper with a carbonaceous film (Specimen 2). For electrochemical experiments and carbon coating, the surfaces of all 
specimens were polished with 1000-grit silicon carbide ( $\mathrm{SiC}$ ) paper, rinsed with ethanol, and dried with $\mathrm{N}_{2}$ gas. To fabricate the specimen $2,10 \mu \mathrm{L} / \mathrm{cm}^{2}$ drawing lubricant was dropped on $1 \mathrm{~cm}^{2}$ copper substrate, and then the copper substrate was heated at $300{ }^{\circ} \mathrm{C}$ for $1 \mathrm{~h}$ in a furnace. The heating temperature complies with the ASTM B88 standard, which is the soft annealing standard of C12200 copper [21,22]. At this temperature, the fatty ester, a constituent of the drawing lubricant, polymerizes through oxidation [23]. Table 2 presents the chemical composition of the drawing lubricant. A carbonaceous film was formed on the copper substrate during annealing. After annealing, specimen 2 was repolished with 1000-grit $\mathrm{SiC}$ paper to remove the half area of carbonaceous film. To assess whether the carbonaceous film is formed well on copper by soft annealing, SEM/EDS (SEM-7800F Prime, JEOL Ltd., Tokyo, Japan) analysis was performed on the specimen. In addition, to clarify the precise cross-sectional structure of carbonaceous film, the carbonaceous film was formed on a brittle material, Si wafer, and the cross-section of the unpolished carbonaceous film was analyzed after being broken by freezing in liquid nitrogen. The prepared specimens are tested in synthetic tap water containing 0 and 540 ppm BTA ( $>99 \%$, commercially purchased, Samchun Chemical, Seoul, Korea) at $25^{\circ} \mathrm{C}$ and $\mathrm{pH}$ 7.2. The BTA concentration was determined from the amount of the BTA component of the commercial inhibitor-Fernox ${ }^{\circledR}$ Alphi [24]. Table 3 presents the chemical composition of the synthetic tap water used in testing. $\mathrm{NaCl}, \mathrm{Mg}(\mathrm{OH})_{2}, \mathrm{CaCO}_{3}$, and $\mathrm{H}_{2} \mathrm{SO}_{4}$ were used to adjust the chemical composition of the synthetic tap water, and $0.1 \mathrm{M} \mathrm{HNO}_{3}$ solution was used to control the $\mathrm{pH}$ level.

Table 2. Chemical composition of drawing lubricant (wt.\%).

\begin{tabular}{cc}
\hline Elements & Composition \\
\hline Polyisobutylene (PIB) & $80-85$ \\
Fatty ester & $15-20$ \\
\hline
\end{tabular}

Table 3. Chemical composition of synthetic tap water (ppm) used in testing.

\begin{tabular}{cccccc}
\hline $\mathbf{p H}$ & $\mathbf{C l}^{-}$ & $\mathbf{M g}^{2+}$ & $\mathbf{C a}^{2+}$ & $\mathbf{S O}_{4}{ }^{2-}$ & BTA \\
\hline 7.2 & 15.8 & 12.9 & 51.7 & 13.2 & 0,540 \\
\hline
\end{tabular}

\subsection{X-ray Photoelectron Spectroscopy (XPS)}

XPS was performed with a commercial ESCA system (Axis Supra ${ }^{\mathrm{TM}}$, Kratos, Manchester, $\mathrm{UK}$ ). The excitation source was $\mathrm{Al} \mathrm{K} \alpha$ radiation (photoelectron energy $=1486.6 \mathrm{eV}$ ). Survey scan spectra were recorded at pass energy of $160 \mathrm{eV}$, and high-resolution spectra were recorded at pass energy of $20 \mathrm{eV}$ with an energy step of $0.1 \mathrm{eV}$. XPS spectra were recorded on specimen 2 during 24-h immersion at the open circuit potential in tap water with and without the addition of 540 ppm BTA. Then, the specimens were rinsed with ethanol and dried. To analyze the adsorption of BTA in the presence of the carbonaceous film on specimen 2, three parts of the specimen (copper part, carbonaceous part, and copper-carbonaceous film boundary part) were measured according to the presence or absence of BTA, as shown in Figure S1.

Spectra were deconvoluted as $\mathrm{Cu}, \mathrm{N}$, and $\mathrm{Cl}$. $\mathrm{Cu}$ was analyzed as both Auger spectra and XPS spectra for more accurate analysis. In Auger $\left[\mathrm{Cu}\left(\mathrm{L}_{3} \mathrm{M}_{4,5} \mathrm{M}_{4,5}\right)\right]$ spectra, the major $\mathrm{Cu}$ Auger peak is observed at the binding energy, $E_{b}$, of $568.2 \mathrm{eV}$, and that of $\mathrm{Cu}_{2} \mathrm{O}$ is observed at $570 \mathrm{eV}$ [25-28]. In $\mathrm{Cu} 2 \mathrm{p}_{3 / 2} \mathrm{XPS}$ spectra, the $\mathrm{Cu} 2 \mathrm{p}_{3 / 2}$ peak of $\mathrm{Cu}$ is observed at $932.7 \mathrm{eV}$ and that of $\mathrm{Cu}_{2} \mathrm{O}$ is observed at $932.5 \mathrm{eV}$ [29-32]. In addition, the peak in N 1s, which is a component of BTA, is observed between 397.9 and $401 \mathrm{eV}$ [25]. The $\mathrm{Cl} 2 \mathrm{p}$ peak of chlorine in $\mathrm{CuCl}$ is observed at $198.0 \mathrm{eV}$ [32-34]. 


\subsection{Electrochemical Tests}

The corrosion properties of the specimens were evaluated using a potentiodynamic polarization test and EIS test. All electrochemical experiments were conducted after 24-h immersion using VSP 300 (Bio-Logic SAS, Seyssinet-Pariset, France). To conduct the potentiodynamic polarization test and EIS test, a three-electrode system consisting of two specimens (specimen 1 and specimen 2 ) as the working electrodes (WE), two pure graphite rods as the counter electrodes (CE), and a saturated calomel electrode (SCE) with a Luggin capillary as the reference electrode (RE) was used. The potentiodynamic polarization test based on the presence or absence of the BTA inhibitor was conducted at a potential sweep of $0.166 \mathrm{mV} / \mathrm{s}$ from $-250 \mathrm{mV}$ vs. open-circuit potential (OCP) to $1600 \mathrm{mV}_{\mathrm{SCE}}$. The EIS test was conducted with an amplitude of $20 \mathrm{mV}$ and a frequency of $100 \mathrm{kHz}$ to $1 \mathrm{mHz}$. Impedance plots were analyzed on the basis of an equivalent circuit through the ZsimpWin program (ZsimpWin 3.20, Echem Software, Warminster, PA, USA) using the appropriate fitting procedure.

\subsection{Surface Analysis after Potentiostatic Polarization Test}

To investigate the effect of BTA on the carbonaceous film-coated copper, the surface morphology and cross-section analyses were performed by SEM/EDS (SEM-7800F Prime, JEOL Ltd., Tokyo, Japan) after a potentiostatic polarization test. The potentiostatic polarization test was conducted using specimen 2 and at a constant potential of $300 \mathrm{mV}_{\mathrm{SCE}}$. The total coulombic charge was $0.0033 \mathrm{mAh}$ and $1.52 \mathrm{mAh}$, respectively, in the presence or absence of BTA. In the presence of BTA, a $\mathrm{Cu}$-BTA passive film forms and the corrosion rate differs from that of bare copper, so the coulombic charge also differs [7]. The total amount of coulombic charge was obtained by calculating the amount of charge when accelerated for 6 months with each corrosion current density.

\section{Results and Discussion}

\subsection{Carbonaceous Film Coating Analysis}

The cross-section of the copper-coated with the carbonaceous film was analyzed using SEM/EDS. Figure 2a is the cross-sectional image of the copper part, and Figure $2 b$ is the cross-sectional image of the carbonaceous film part on the copper. The carbonaceous film formed on the copper surface has a thickness of $20 \mu \mathrm{m}$. EDS data indicate that the carbonaceous film is composed of $\mathrm{C}$ and $\mathrm{O}$ in the drawing lubricant components (Figure 2c). Figure S2 is a cross-sectional electron probe micro analyzer (EPMA) image which was observed near pitting corrosion of a copper pipe for a sprinkler used for 11 years. Figure S2a shows that the carbonaceous film is formed with a thickness of $10-20 \mu \mathrm{m}$. Figure S2b shows that the carbonaceous film has the same composition as drawing lubricant components, which is $\mathrm{C}$ and $\mathrm{O}$. This means that carbonaceous residues are present on copper pipes in real field and consistent with the carbonaceous film formed on the specimens in the experiments.

In Figure 3, the carbonaceous film is not completely adsorbed on the substrate and has a granular form and a porous structure with hollow parts. This may cause localized corrosion by crevice corrosion at the boundaries and defects of the carbonaceous film. 


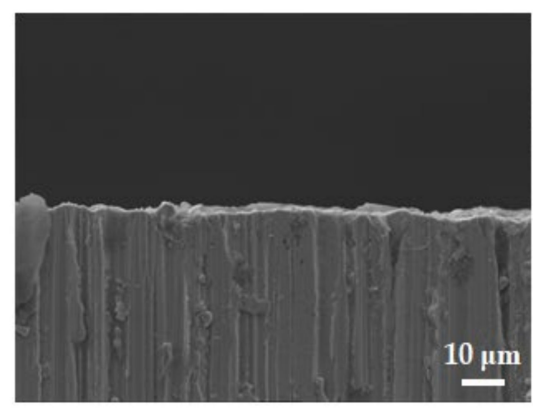

(a)

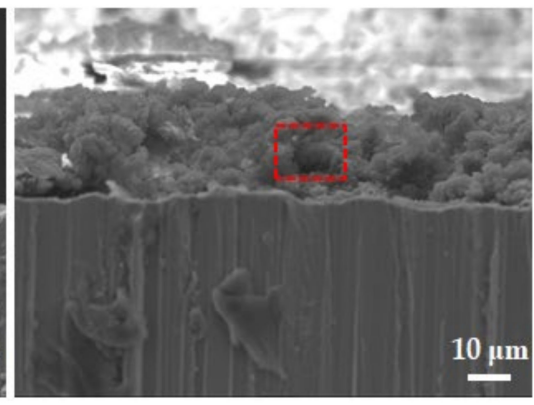

(b)

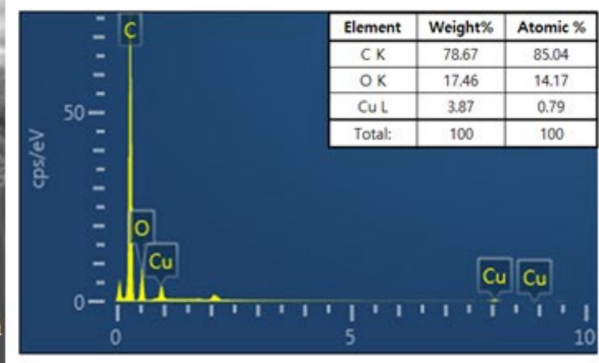

(c)

Figure 2. Cross-sectional SEM images of the specimens; (a) SEM images of specimen 1 (1000 $\times$ ); (b) SEM images of the carbonaceous film on specimen $2(1000 \times)$; (c) EDS result of the carbonaceous film (red dotted-box).

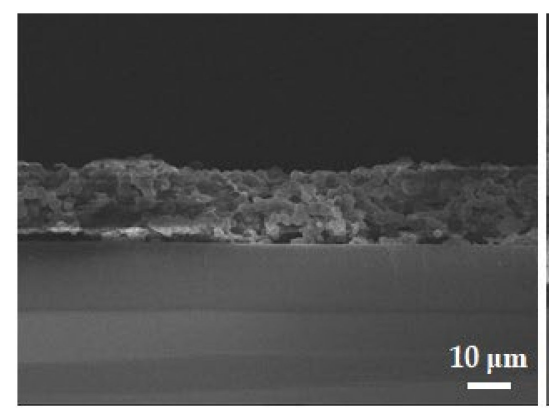

(a)

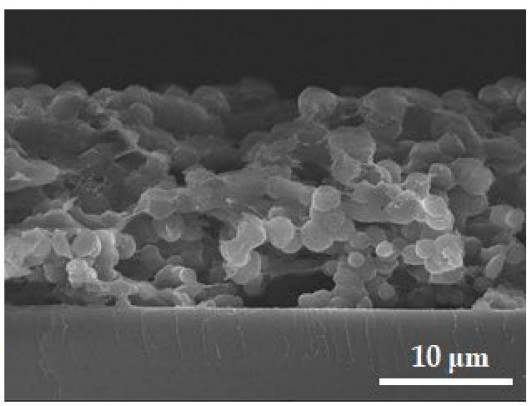

(b)

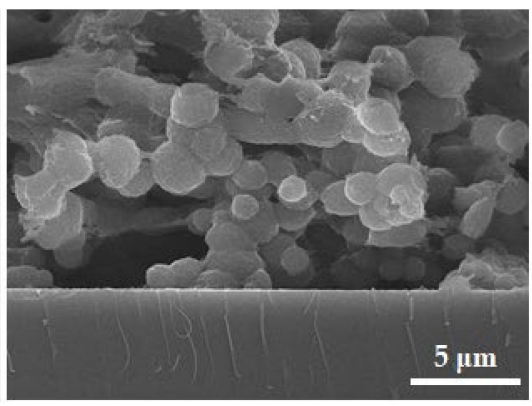

(c)

Figure 3. Cross-sectional SEM images of carbonaceous film on Si wafer; (a) $1000 \times$; (b) $3000 \times$; (c) $5000 \times$.

\subsection{XPS Analysis}

Figure 4 shows the XPS analysis of specimen 2 after immersed in synthetic tap water for $24 \mathrm{~h}$ with and without the addition of BTA $540 \mathrm{ppm}$. Based on the existence of the BTA, each analysis was conducted on the three parts in specimen 2 to confirm the change in the copper corrosion surface layer due to the carbonaceous film. Since XPS analyses were performed with different specimens under different conditions, only qualitative analyses were performed. Regardless of the presence or absence of BTA, the first peak was observed in the range of 569.4-569.8 eV in the Cu LMM Auger spectra at all three parts. This corresponds to the results in a previous study, where the center of the Cu LMM Auger peak was $568.2 \mathrm{eV}$, the center of the $\mathrm{Cu}$ LMM Auger peak for $\mathrm{CuO}$ was $569.2 \mathrm{eV}$, and the center of the $\mathrm{Cu}$ LMM Auger peak for $\mathrm{Cu}_{2} \mathrm{O}$ was $570 \mathrm{eV}$ [25-27]. W Liu et al. suggested that the $\mathrm{Cu}$ LMM Auger peak in the range of $569-570 \mathrm{eV}$ was due to the formation of $\mathrm{CuO} / \mathrm{Cu}_{2} \mathrm{O}$ [26]. Figure S3 shows the $\mathrm{Cu}$ LMM Auger spectra and deconvoluted results for the copper surface in the presence and absence of BTA. From the results, it can be inferred that the specimen surface is composed of $\mathrm{Cu}, \mathrm{CuO}$ and $\mathrm{Cu}_{2} \mathrm{O}$, regardless of the presence or absence of BTA. Similarly, in the $\mathrm{Cu} 2 \mathrm{p}_{3 / 2}$ XPS spectra, the first peak was observed at $932.2 \mathrm{eV}$, whereas the $\mathrm{Cu} 2 \mathrm{p}_{3 / 2}$ peak of $\mathrm{Cu}_{2} \mathrm{O}$ was observed at $932.5 \mathrm{eV}$, and the $\mathrm{Cu} 2 \mathrm{p}_{3 / 2}$ peak of $\mathrm{Cu}$ was observed at $932.7 \mathrm{eV}$ [29-31]. $\mathrm{Cu}$ and $\mathrm{Cu}_{2} \mathrm{O}$ appear to exist on copper surfaces regardless of the existence of the BTA. The observation of copper peaks in the carbonaceous parts may be due to the oxidation of copper through the porous structure of the carbonaceous film. 


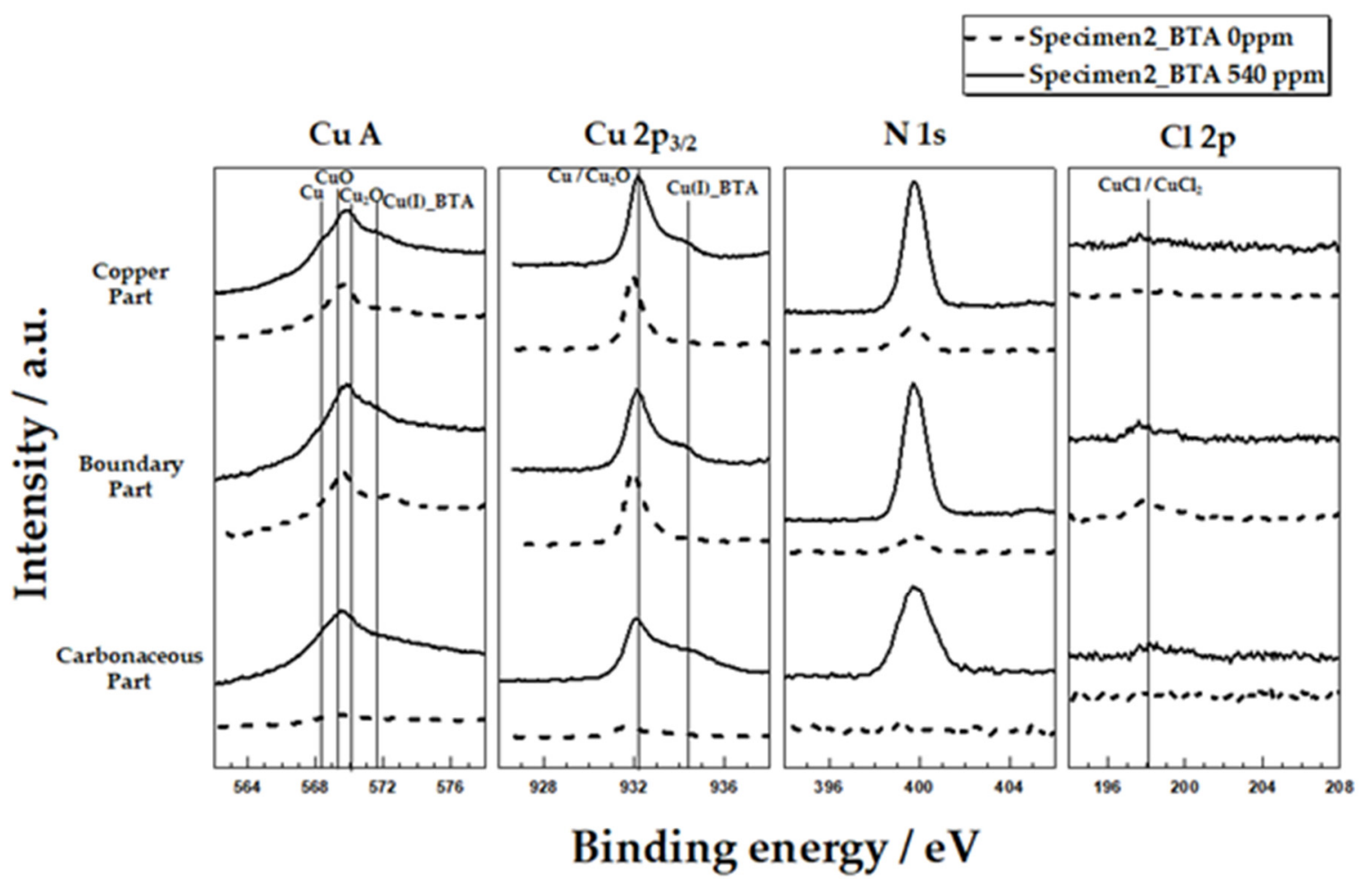

Figure 4. Cu LMM X-ray induced spectra and $\mathrm{Cu} 2 \mathrm{p} 3 / 2, \mathrm{~N} 1 \mathrm{~s}$, and $\mathrm{Cl} 2 \mathrm{p}$ XPS spectra recorded at the surface of copper after 24-hour immersion in synthetic tap water at $25{ }^{\circ} \mathrm{C}$ based on the presence and absence of BTA.

The second peak was observed at $571.8 \mathrm{eV}$ in the $\mathrm{Cu}$ LMM Auger spectra in the three parts of specimen 2 with BTA. Similarly, a second peak was observed at $934.4 \mathrm{eV}$ in the $\mathrm{Cu} 2 \mathrm{p}_{3 / 2}$ XPS spectra. This is consistent with the observations in previous studies, where the $\mathrm{Cu}(\mathrm{I})-\mathrm{BTA}$ peak was observed at $571.8 \mathrm{eV}$ in the $\mathrm{Cu}$ LMM Auger spectra and $934.8 \mathrm{eV}$ in the $\mathrm{Cu} 2 \mathrm{p}_{3 / 2}$ XPS spectra [25,30]. This peak was not observed in specimen 2 without BTA. In addition, N 1s XPS peak, which is a component of BTA, was observed at $399.5 \mathrm{eV}$ in three parts of specimen 2 in the presence of BTA [32]. This means that that $\mathrm{Cu}-\mathrm{BTA}$ complex is well formed on all parts in the specimen with carbonaceous film.

The $\mathrm{Cl} 2 \mathrm{p}$ XPS spectra were analyzed to confirm localized corrosion caused by the carbonaceous film. Unlike other parts, $198 \mathrm{eV}$ of the $\mathrm{Cl} 2 \mathrm{p}$ peak was detected in the boundary parts of specimen 2 [32]. $\mathrm{Cl} 2 \mathrm{p}$ peak results that the generation of $\mathrm{CuCl}$ and $\mathrm{CuCl}_{2}$ increased at the boundary of the carbonaceous film. It is known that the formation of $\mathrm{CuCl}$ and $\mathrm{CuCl}_{2}$ increases at the $\mathrm{Cl}$ concentration increasing site, causing localized corrosion [4]. That is, it was estimated that the formation of $\mathrm{CuCl}$ and $\mathrm{CuCl}_{2}$ increased with the increase in the $\mathrm{Cl}$ concentration in the boundary part.

\subsection{Electrochemical Analysis}

\subsubsection{Potentiodynamic Polarization Measurements}

Figure 5 shows the potentiodynamic polarization curves for specimen 1 and specimen 2 in synthetic tap water at $25^{\circ} \mathrm{C}$ in the presence and absence of BTA. When BTA was added to the solutions, a more noble corrosion potential and the lower corrosion current density were observed. This could be due to the $\mathrm{Cu}$-BTA complex formation, as BTA was adsorbed on the copper surface. Generally, the Cu-BTA complex formation acts as a mixed-type inhibitor to retard the oxidation of copper and reduction in oxygen [7,9]. The breakdown potential $\left(E_{b}\right)$ seen in the BTA-added specimens indicated that the $\mathrm{Cu}$-BTA complex has an effective passive property [9]. Notably, the $\mathrm{Cu}$-BTA complex acts more effectively as an anodic corrosion inhibitor [32]. In Figure 5, the apparent increase in the anodic Tafel 
slope value and shift in corrosion potential $\left(E_{\text {corr }}\right)$ to the noble direction is due to the more effective reduction in the anodic reaction than in the cathodic reaction.

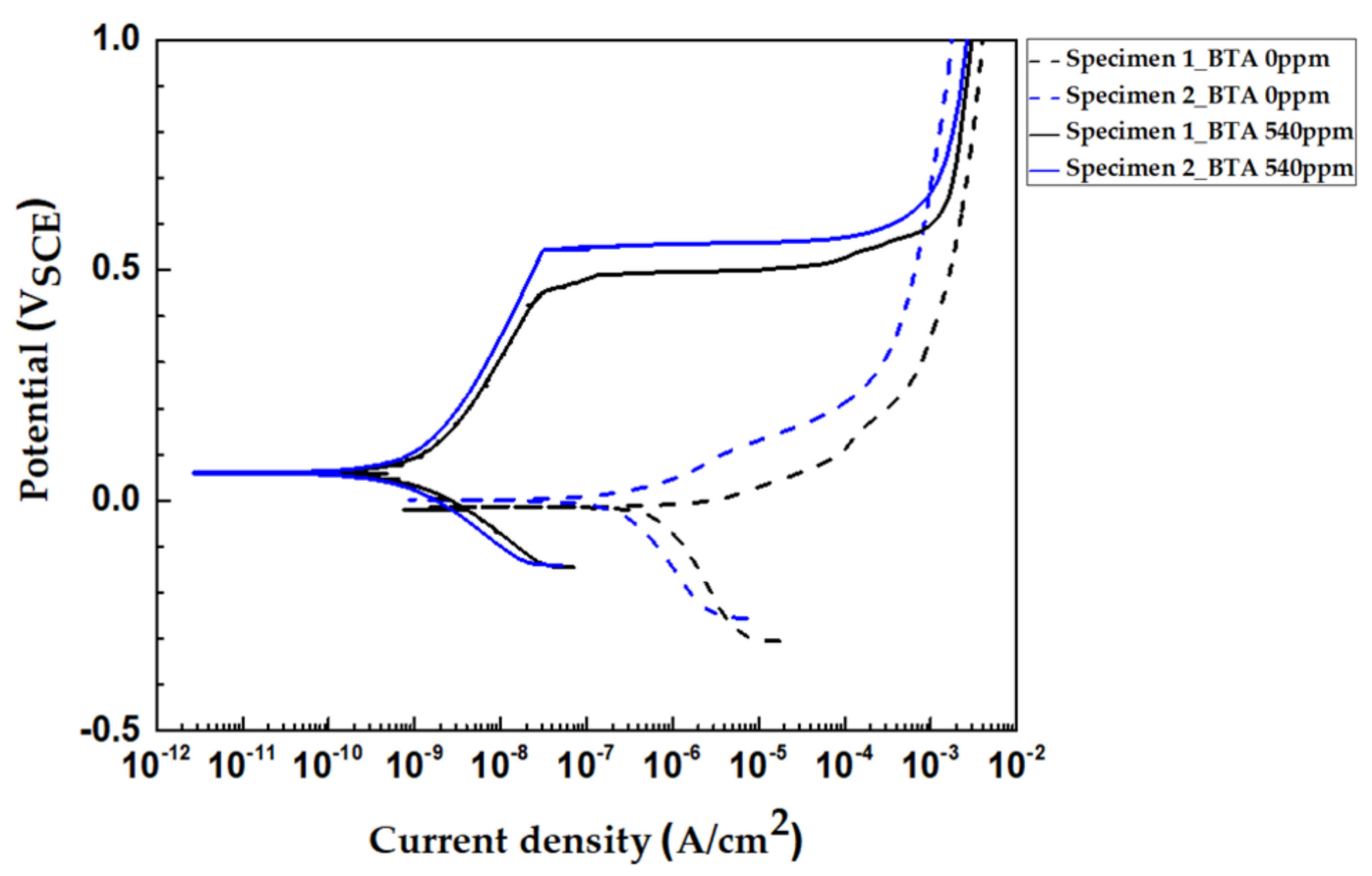

Figure 5. Potentiodynamic polarization curves for specimen 1 and specimen 2 in synthetic tap water at $25^{\circ} \mathrm{C}$ according to the presence and absence of BTA.

Table 4 lists the electrochemical parameters that were obtained from polarization curves on specimen 1 and specimen 2 in synthetic tap water at $25^{\circ} \mathrm{C}$ with the BTA presence and absence. Regardless of the presence or absence of BTA, as shown in Figure 5 and Table 4 , specimen 2 had a lower corrosion current density $\left(i_{\text {corr }}\right)$ and similar or higher $E_{\text {corr }}$ compared to specimen 1 . Raman and Zhang reported that $i_{\text {corr }}$ is decreased and $E_{\text {corr }}$ adjusted more toward a positive direction when metal is coated with a graphene or carbon layer $[35,36]$. They suggested that the carbon layer or graphene reduced the dissolution of metal, thereby decreasing the corrosion rate by 2-3 times, and increased corrosion resistance, thereby moving $E_{\text {corr }}$ toward a more positive direction. In specimen 2, only half of the area was coated with the carbonaceous film, so it can be expected that $i_{\text {corr }}$ is reduced to half value. The $i_{\text {corr }}$ of specimen 2 was approximately half relatively to that of specimen 1 regardless of the existence of BTA in the solution.

Table 4. Electrochemical parameters from polarization measurements on specimen 1 and specimen 2 in synthetic tap water at $25^{\circ} \mathrm{C}$ based on the presence and absence of BTA.

\begin{tabular}{|c|c|c|c|c|c|}
\hline Specimen & $\begin{array}{c}C_{B T A} \\
(\mathrm{ppm})\end{array}$ & $\begin{array}{c}E_{\text {corr }} \\
\left(\mathrm{mV}_{\mathrm{SCE}}\right)\end{array}$ & $\begin{array}{c}i_{\text {corr }} \\
\left(\mathrm{nA} / \mathrm{cm}^{2}\right)\end{array}$ & $\begin{array}{c}E_{b} \\
\left(m V_{S C E}\right)\end{array}$ & $I E \%$ \\
\hline \multirow{2}{*}{ Specimen 1} & 0 & -17.83 & 759.95 & - & - \\
\hline & 540 & 60.27 & 1.32 & 451.89 & 99.83 \\
\hline \multirow{2}{*}{ Specimen 2} & 0 & -2.83 & 351.51 & - & - \\
\hline & 540 & 56.87 & 0.76 & 544.14 & 99.78 \\
\hline
\end{tabular}

Inhibiting efficiency $(I E \%)$ can be calculated using the following Equation (1) [9,32];

$$
I E \%=100 \times\left[\frac{\left(i_{\text {corr }}^{0}-i_{\text {corr }}\right)}{i_{\text {corr }}^{0}}\right]
$$


where $i_{c o r r}^{0}$ and $i_{\text {corr }}$ are the corrosion current densities in the absence and presence of the inhibitor in the solution, respectively. Specimen 1 and specimen 2 have high corrosion $I E \%$ at $99.83 \%$ and $99.78 \%$. It is clear that copper with the carbonaceous film showed a similar BTA adsorption rate and stability as bare copper.

\subsubsection{Electrochemical Impedance Spectroscopy (EIS)}

Figure 6 shows the Nyquist plots that were obtained for specimen 1 and specimen 2 in synthetic tap water in the presence and absence of BTA. When BTA is added, it is shown in Figure 6 that both specimen 1 and specimen 2 increased the capacitive loop as well as corrosion inhibition efficiency. Figure 6 also shows the equivalent circuit for copper based on the presence and absence of BTA $[29,32,37]$. The proposed equivalent circuit fits well with EIS data. The equivalent circuit comprised the following elements. $R_{S}$ is the solution resistance. $R 1$ is the resistance due to defects in the layer formed over copper or the formation of ionic conduction paths through pores. In the absence of BTA, resistance is due to copper oxide, and in the presence of BTA, resistance is due to $\mathrm{Cu}$-BTA complex formation $[29,32,37]$. CPE1 is the barrier capacitance corresponding to $R 1, R_{c t}$ is the charge transfer resistance, and CPE2 is the capacitance due to the electric double layer generated at the interface between the rust/ barrier and metal substrates. The constant phase element $(C P E)$ is a non-ideal capacitance with a varying $n$, expressed by Equation $(2)[9,25,36,38]$

$$
Q=Z_{C P E}=\frac{1}{Y_{0}(j \omega)^{n}}
$$

where $Y_{0}$ is the magnitude of the $C P E$, and $n$ is a parameter by frequency dispersion. The parameter $n$ is affected by non-homogeneity and surface roughness [9]. When $n=1, Q$ represents the ideal capacitor $C$, and when $n=0, Q$ becomes a simple resistor. Parameter $n$ generally has a value of $0.5-1$, and $n=0.5$ indicates a process in which copper ions are diffused through the pores of the oxide layer $[9,25]$. Table 5, which is calculated from EIS data, shows that the value of $n_{1}$ is close to 0.5 for both specimen 1 and specimen 2 in the absence of BTA, and the value of $n_{1}$ is close to 1 for both specimen 1 and specimen 2 in the presence of BTA. It can be regarded as the diffusion of copper ions through the defects of a copper oxide layer in the absence of the BTA, and formation of the $\mathrm{Cu}$-BTA complex in the presence of the BTA. The $\mathrm{Cu}$-BTA complex formation acts as an ideal capacitor and a barrier.

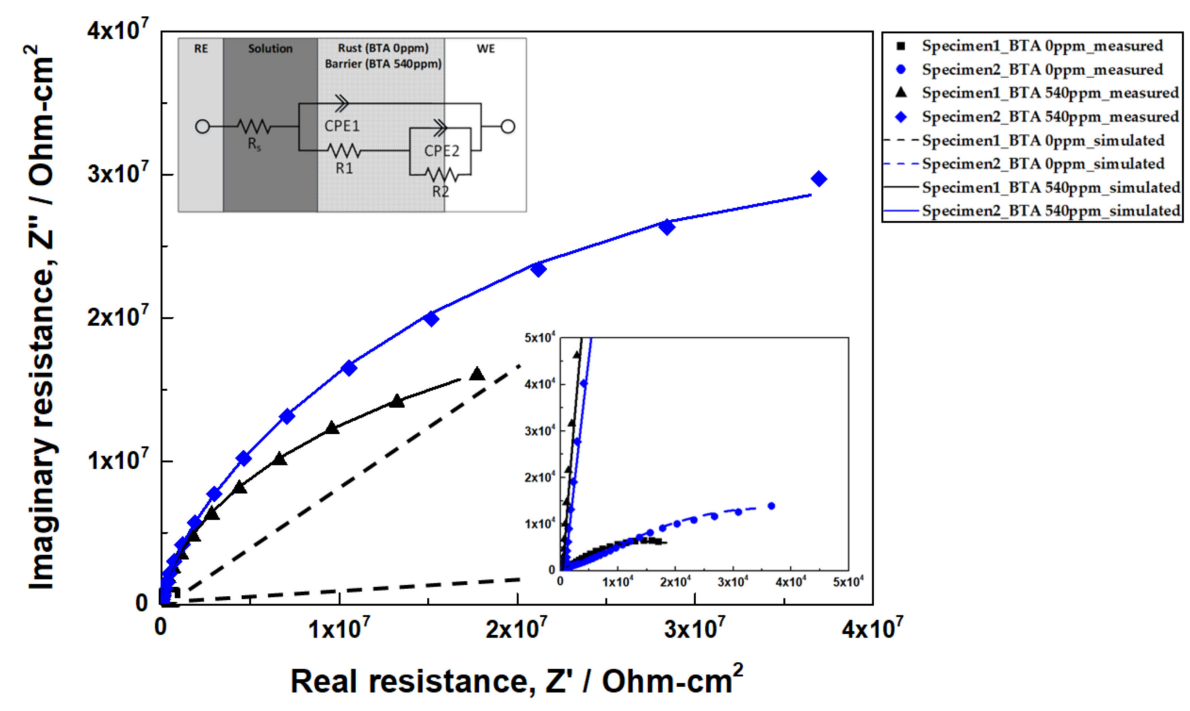

Figure 6. Nyquist plots for specimen 1 and specimen 2 and equivalent circuit for fitting in synthetic tap water at $25^{\circ} \mathrm{C}$ based on the presence and absence of BTA. 
Table 5. Electrochemical parameters from EIS measurements on specimen 1 and specimen 2 in synthetic tap water at $25^{\circ} \mathrm{C}$ based on the presence and absence of BTA.

\begin{tabular}{|c|c|c|c|c|c|c|c|c|c|}
\hline Specimen & $\begin{array}{c}C_{B T A} \\
(\mathrm{ppm})\end{array}$ & $\begin{array}{c}R_{s} \\
\left(\Omega-\mathrm{cm}^{2}\right)\end{array}$ & $\begin{array}{c}R 1 \\
\left(\Omega-\mathrm{cm}^{2}\right)\end{array}$ & $\begin{array}{c}C P E 1 \\
\left(\mathrm{~F} / \mathrm{cm}^{2}\right)\end{array}$ & $n_{1}$ & $\begin{array}{c}R 2 \\
\left(\Omega-\mathrm{cm}^{2}\right)\end{array}$ & $\begin{array}{c}C P E 2 \\
\left(\mathrm{~F} / \mathrm{cm}^{2}\right)\end{array}$ & $n_{2}$ & $I E \%$ \\
\hline \multirow{2}{*}{ Specimen 1} & 0 & $2.49 \times 10^{2}$ & $1.86 \times 10^{3}$ & $2.22 \times 10^{-5}$ & 0.66 & $2.72 \times 10^{4}$ & $9.00 \times 10^{-5}$ & 0.51 & - \\
\hline & 540 & $4.35 \times 10^{2}$ & $8.14 \times 10^{6}$ & $1.51 \times 10^{-6}$ & 0.96 & $2.94 \times 10^{7}$ & $4.59 \times 10^{-7}$ & 0.66 & 99.92 \\
\hline \multirow{2}{*}{ Specimen 2} & 0 & $6.78 \times 10^{2}$ & $7.36 \times 10^{3}$ & $4.74 \times 10^{-5}$ & 0.49 & $6.03 \times 10^{4}$ & $1.59 \times 10^{-4}$ & 0.51 & - \\
\hline & 540 & $8.15 \times 10^{2}$ & $1.07 \times 10^{7}$ & $6.01 \times 10^{-7}$ & 0.95 & $6.75 \times 10^{7}$ & $1.54 \times 10^{-7}$ & 0.58 & 99.91 \\
\hline
\end{tabular}

The total amount of resistance and inhibitor efficiency (IE\%) are calculated using Equations (3) and (4) [9]

$$
\begin{gathered}
R_{\text {total }}=R 1+R 2 \\
I E \%=100 \times\left(\frac{R_{\text {total }}-R_{\text {total }}^{0}}{R_{\text {total }}}\right)
\end{gathered}
$$

In Equation (3), $R_{\text {total }}$ has a direct correlation with corrosion resistance [35]. In Equation (4), $R_{\text {total }}$ and $R^{0}$ total are total resistance in the presence and absence of BTA, respectively. Figure 7a shows the $R_{\text {total }}$ value based on the presence or absence of BTA in specimen 1 and specimen 2 . Both the $R_{\text {total }}$ and $R_{\text {total }}^{0}$ of specimen 2 increased by approximately 2 times compared to the resistances of specimen 1 . Half of the specimen 2 was coated with a carbonaceous film. It can be expected that the area coated with a carbonaceous film of specimen 2 has high resistance, so that, only the area uncoated with the carbonaceous film is measured [35,36]. Therefore, the resistance of specimen 2 is doubled compared to specimen 1 because only half area of the specimen 1 is measured. Figure $7 \mathrm{~b}$ shows the IE\% obtained from PD and EIS for copper based on the presence and absence of BTA. The $I E \%$ values obtained from PD and EIS show a tendency to slightly decrease the efficiency in specimen 2. This is presumed to be due to the changes in the $\mathrm{Cu}-\mathrm{BTA}$ complex formation by the carbonaceous film of specimen 2. According to the XPS results, the $\mathrm{Cl}$ concentration increased at the boundary of the carbonaceous film of specimen 2 . The alteration in the corrosive environment at the boundary may change the mechanism of the $\mathrm{Cu}-\mathrm{BTA}$ complex formation. However, the $I E \%$ of specimen 2 from PD and EIS data shows very high efficiencies of 99.78 and $99.91 \%$, respectively. Therefore, BTA corrosion inhibitor is sufficient to suppress corrosion in copper covered with the carbonaceous film.

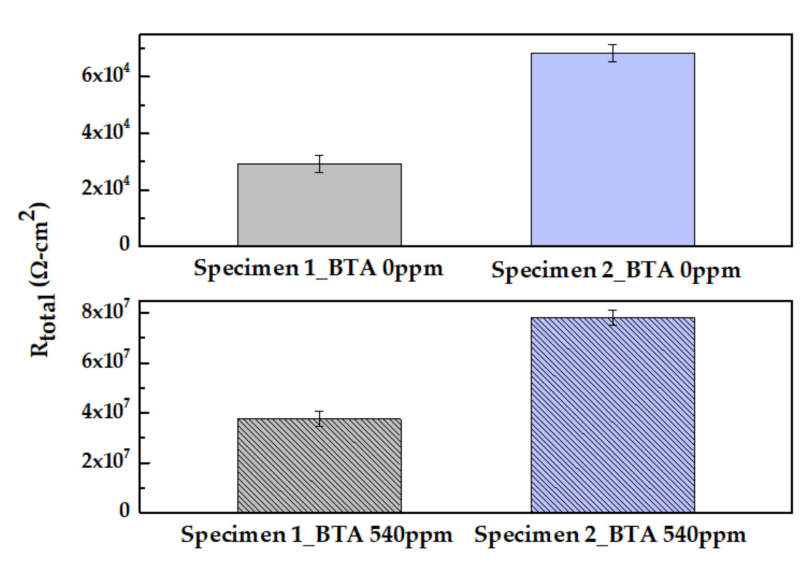

(a)

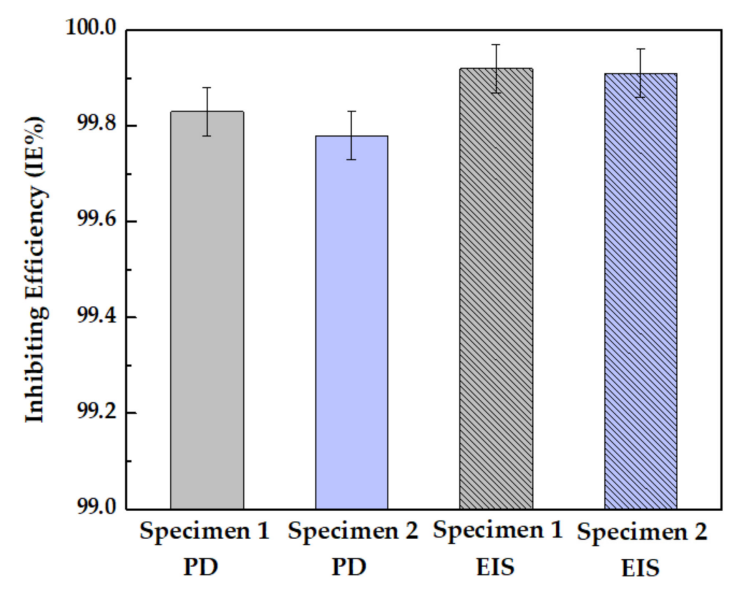

(b)

Figure 7. (a) The value of the total resistance of copper as a function of BTA; (b) The inhibiting efficiency (IE\%) of copper as a function of BTA from potentiodynamic (PD) polarization curve and EIS. 


\subsection{Surface Analysis after Potentiostatic Polarization Test}

Figure 8 shows the results of the element mapping analysis of the specimen 2 after potentiostatic polarization test as the BTA presence and absence. Uniform corrosion occurred in the copper part or carbonaceous film part of the specimen 2 when BTA was not added, whereas the corrosion behavior was different in the boundary part of the specimen 2 . Figure $8 \mathrm{a}$, $\mathrm{b}$ shows EDS mapping analyses of the boundary part of the surface section of the specimen 2 based on the absence and presence of BTA, respectively. Under both conditions, $\mathrm{C}$ and $\mathrm{O}$, constituents of the drawing lubricant, were detected in the carbonaceous film part. $\mathrm{Cu}$ and $\mathrm{O}$ were detected in the copper part. This is because $\mathrm{Cu}_{2} \mathrm{O}$ was formed in the copper part [29]. However, in Figure 8b, only a little of the O element is detected in the $\mathrm{Cu}$ part compared to that shown in Figure 8a. This is because the formation of $\mathrm{Cu}_{2} \mathrm{O}$ was restricted due to the formation of the $\mathrm{Cu}-\mathrm{BTA}$ complex $[7,32]$.
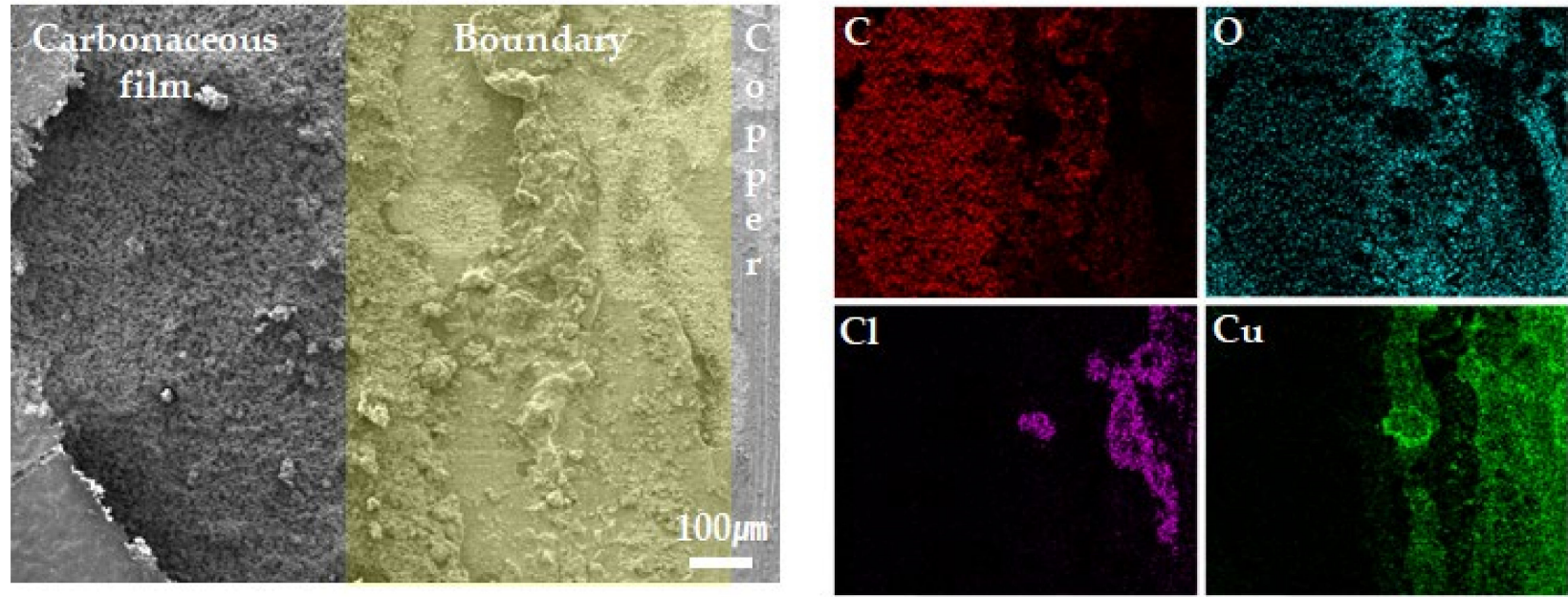

(a)
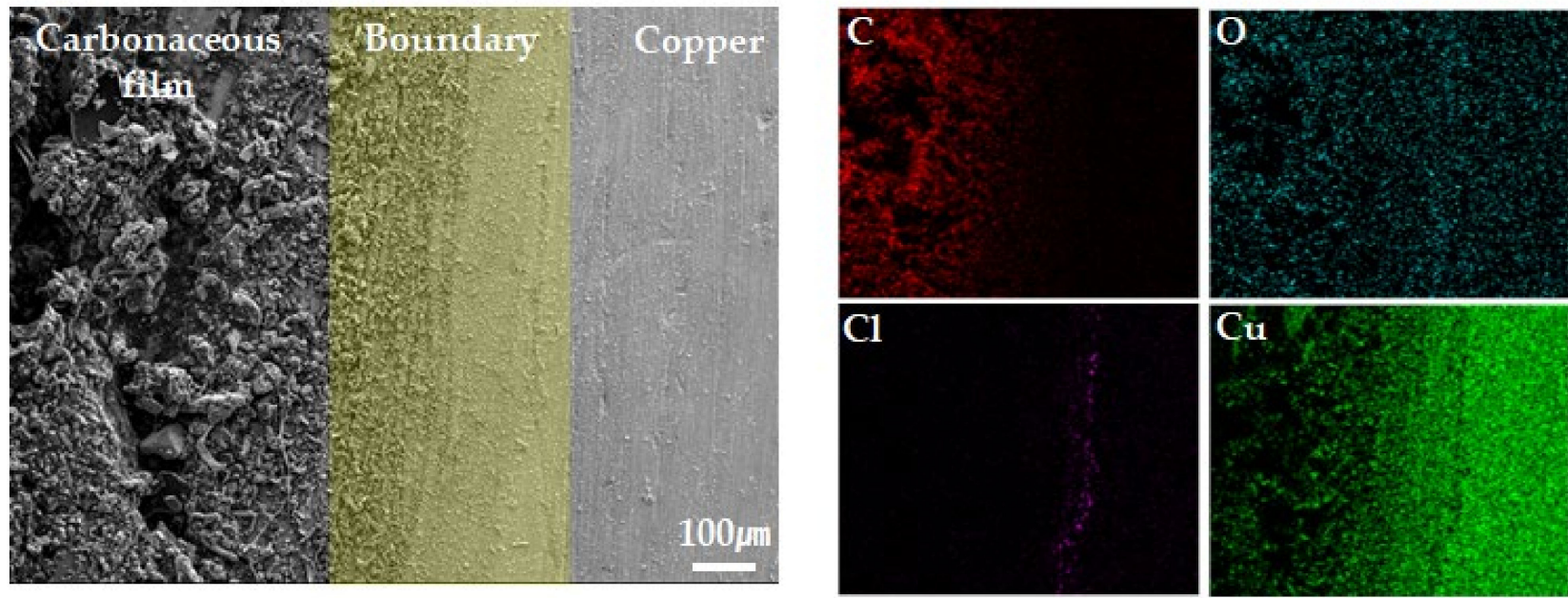

(b)

Figure 8. Cont. 

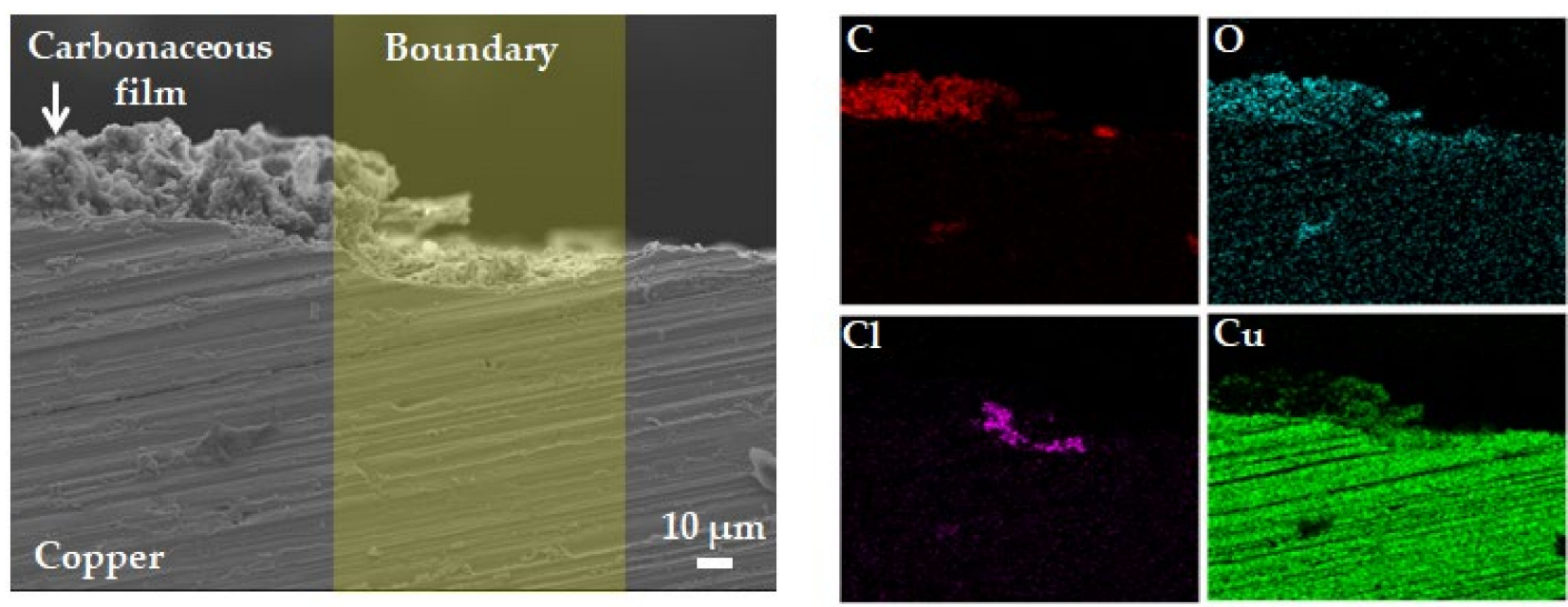

(c)
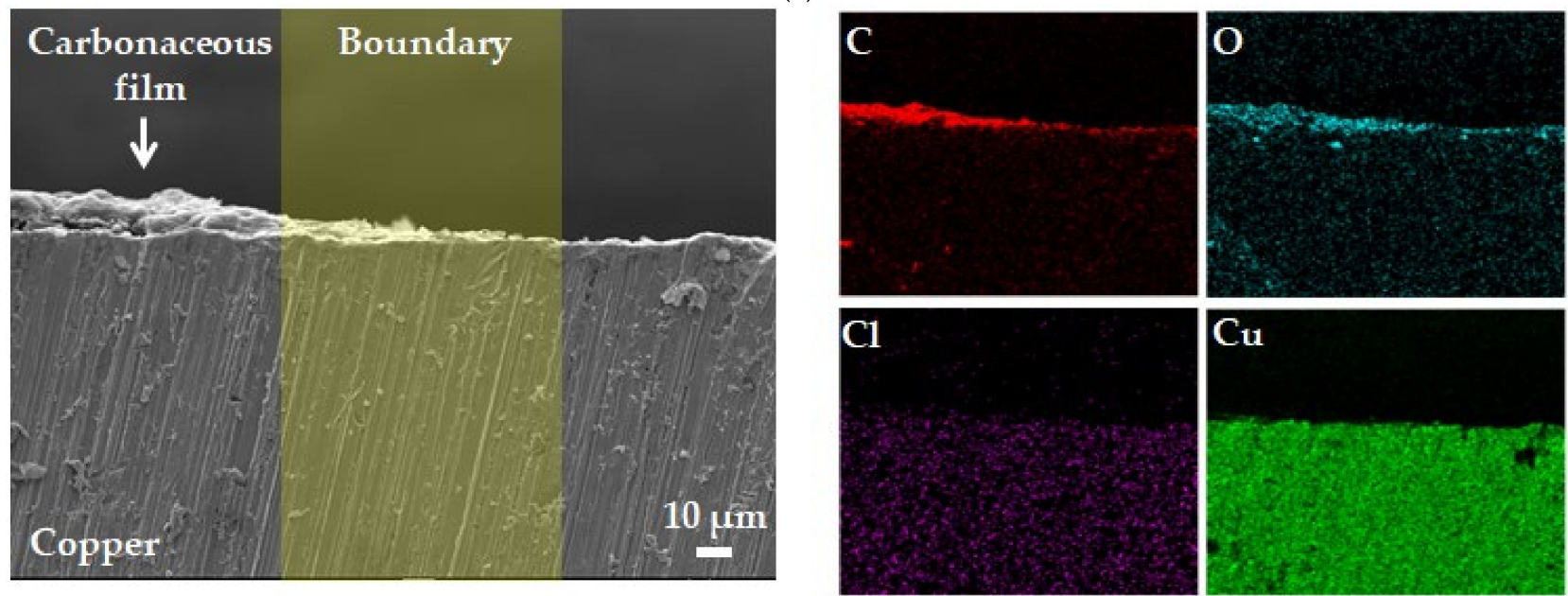

(d)

Figure 8. EDS mapping analysis of the copper-carbonaceous film boundary parts of specimen 2 after potentiostatic polarization test based on the presence or absence of BTA; (a) surface analysis of specimen 2 without BTA; (b) surface analysis of specimen 2 with BTA; (c) cross-section analysis of specimen 2 without BTA; (d) cross-section analysis of specimen 2 with BTA.

Depending on the presence and absence of BTA, EDS mapping analysis is utilized to exhibit the distribution of $\mathrm{Cl}$ at the boundary part of specimen 2. In Figure 8a, a large number of $\mathrm{Cl}$ elements are detected at the boundary part of specimen 2. As $\mathrm{Cu}$ was also detected in the $\mathrm{Cl}$ region, it appears to be due to the formation of $\mathrm{CuCl}$ and $\mathrm{CuCl}_{2}$. However, in Figure 8b, the $\mathrm{Cl}$ element is hardly detected at the boundary of specimen 2. In Figure 8c, which is a condition in the absence of BTA, localized corrosion occurred at the boundary of the carbonaceous film, and the $\mathrm{Cl}$ element was concentrated in that part. However, in Figure $8 \mathrm{~d}$, which is a condition in the presence of BTA, localized corrosion did not occur at the boundary of the carbonaceous film, and a $\mathrm{Cl}$ element was not concentrated. When BTA is added, it appears that the formation of the $\mathrm{Cu}-\mathrm{BTA}$ complex limits the formation of $\mathrm{CuCl}$ and $\mathrm{CuCl}_{2}$ and prevents the concentration of $\mathrm{Cl}$. The related corrosion mechanisms are proposed below.

Several researchers have studied the corrosion behavior of copper. The corrosion behavior of copper varies depending on the $\mathrm{Cl}^{-}$concentration in an aqueous solution [39]. Copper reacts according to Equations (5)-(8) as anodic reactions depending on the $\mathrm{Cl}$ concentration in an aqueous solution [4].

$$
\mathrm{Cu} \rightarrow \mathrm{Cu}^{+}+\mathrm{e}^{-}
$$




$$
\begin{gathered}
\mathrm{Cu}^{+}+\mathrm{Cl}^{-} \rightarrow \mathrm{CuCl} \\
2 \mathrm{CuCl}+\mathrm{H}_{2} \mathrm{O} \rightarrow \mathrm{Cu}_{2} \mathrm{O}+2 \mathrm{H}^{+}+2 \mathrm{Cl}^{-} \\
\mathrm{CuCl}+\mathrm{Cl}^{-} \rightarrow \mathrm{CuCl}_{2}^{-}
\end{gathered}
$$

Equation (7) occurs when the $\mathrm{Cl}^{-}$ion concentration is relatively low ( $\mathrm{NaCl}$ electrolytes containing $\mathrm{Cl}^{-}$concentration $<10^{-3} \mathrm{M}$ ), and Equation (8) occurs when $\mathrm{Cl}^{-}$ion concentration is relatively high $\left(\mathrm{NaCl}\right.$ electrolytes containing $\mathrm{Cl}^{-}$concentration $\left.>10^{-2} \mathrm{M}\right)$. The $\mathrm{Cl}^{-}$ ion concentration of synthetic tap water is $15.8 \mathrm{ppm}$, and it is expected that $\mathrm{Cu}_{2} \mathrm{O}$ will be formed by the reaction of Equation (7) on the entire copper surface. It can be seen that $\mathrm{Cu}_{2} \mathrm{O}$ was formed at the copper part in Figure 8a. However, $\mathrm{Cu}_{2} \mathrm{O}$ was not formed and $\mathrm{Cl}$ was concentrated at the boundary part of the carbonaceous film-copper. The carbonaceous film acts as an efficient cathode, and the small gap between carbonaceous film and substrate acts as an anodic site, which accelerates corrosion due to the large cathode-small anode effect [17]. In the same way as in the boundary part, galvanic corrosion occurs between the carbonaceous film and copper, accelerating the corrosion of copper in the boundary part. In addition, as shown in Figure 3, the carbonaceous film does not completely adsorb on the metal surface, creating a gap, and crevice corrosion may occur in the boundary part. Figure $8 \mathrm{c}$ shows that corrosion occurs under the carbonaceous film in the boundary part. When the corrosion occurs in this way, the diffusion of ions in the gap is limited, the inside of the gap is acidified, and high $\mathrm{Cl}^{-}$ion concentration conditions are formed. Corrosion is further accelerated by forming an oxygen-concentration cell with the surrounding area, and Equation (8) occurs inside the gap to produce $\mathrm{CuCl}$ and $\mathrm{CuCl}_{2}^{-}$instead of $\mathrm{Cu}_{2} \mathrm{O}$, a protective oxide layer, resulting in a more corrosive environment [40,41]. At this time, oxygen reduction reaction occurs at the surrounding area according to Equation (9).

$$
\mathrm{O}_{2}+2 \mathrm{H}_{2} \mathrm{O}+4 \mathrm{e}^{-} \rightarrow 4 \mathrm{OH}^{-}
$$

Figure 9a shows a schematic diagram of the localized corrosion mechanism at the boundary part without BTA.

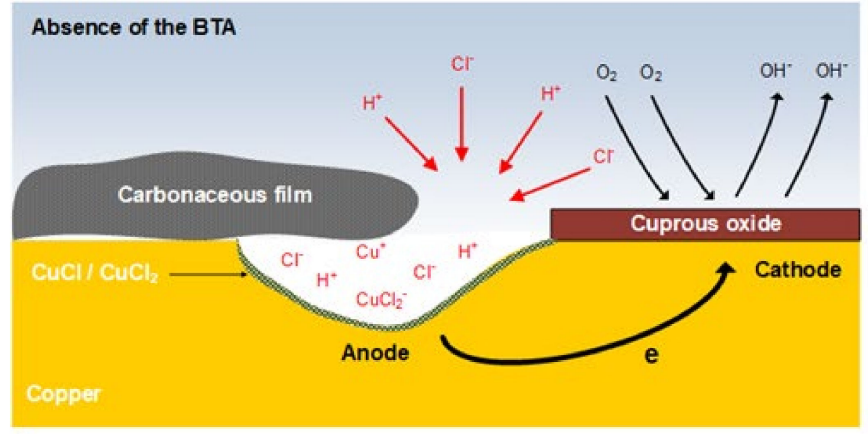

(a)

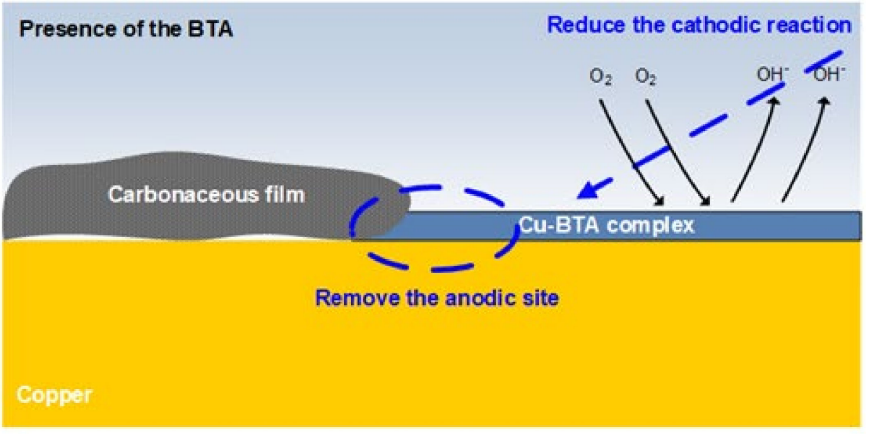

(b)

Figure 9. (a) Schematic diagram of localzed corrosion mechanism at the boundary part of the carbonaceous film of copper in the absence of BTA; (b) schematic diagram of mechanism to prevent localized corrosion at the boundary part of the carbonaceous film of copper in the presence of BTA.

When BTA is added to the solution, the concentration of $\mathrm{Cl}$ in the boundary part disappears and corrosion acceleration does not occur, as shown in Figure $8 b$,d. Figure $9 \mathrm{~b}$ is a schematic diagram of the corrosion prevention mechanism at the boundary part with BTA. When BTA is added to the solution, a $\mathrm{Cu}-\mathrm{BTA}$ complex is formed at the boundary of the carbonaceous film to prevent localized corrosion. Many researchers have reported that $\mathrm{Cu}-\mathrm{BTA}$ protective layer was formed by BTA even in solutions containing $\mathrm{CuCl}$ and $\mathrm{CuCl}_{2}^{-}$[7]. Modestov et al. proposed that BTA acts in a chloride solution according 
to Equation (10) [42]. That is, BTA alleviates localized corrosion by forming a $\mathrm{Cu}-\mathrm{BTA}$ complex at the anodic site at the boundary of the carbonaceous film.

$$
\mathrm{CuCl}_{2}^{-}+\mathrm{BTAH} \rightarrow \mathrm{Cu}-\mathrm{BTA}+2 \mathrm{Cl}^{-}+\mathrm{H}^{+}
$$

Furthermore, when BTA is added to the solution, a $\mathrm{Cu}-\mathrm{BTA}$ complex is formed in the copper part to mitigate the effect of the oxygen-concentration cell. BTA forms $\mathrm{Cu}-\mathrm{BTA}$ complex by Equation (11) in copper parts $[7,9,32]$.

$$
\mathrm{n}(\mathrm{BTAH})_{\mathrm{ads}}+\mathrm{nCu} \rightarrow(\mathrm{Cu}-\mathrm{BTA})_{\mathrm{n}}+\mathrm{nH}^{+}+\mathrm{ne}^{-}
$$

BTA is a mixed-type inhibitor and suppressed the oxygen reduction reaction on the surface of $\mathrm{Cu}$-BTA. That is, BTA mitigates localized corrosion by inhibiting the formation of the oxygen-concentration cell at the boundary of the carbonaceous film.

\section{Conclusions}

The corrosion inhibition effect of BTA on the copper surface with a carbonaceous film in synthetic tap water was investigated using XPS, potentiodynamic polarization, EIS, potentiostatic polarization, and SEM/EDS. According to experimental results, the following conclusions were drawn:

- In solutions containing BTA, Cu-BTA complex and $\mathrm{N}$ elements were detected in the copper part, carbonaceous film-copper boundary part, and carbonaceous film part through XPS analysis. In addition, BTA decreased $i_{\text {corr }}$ and increased $R 1$ and $n_{1}$. This is because BTA adsorbs well on the entire surface of copper with carbonaceous film to form a $\mathrm{Cu}-\mathrm{BTA}$ protective layer;

- $\quad$ XPS and SEM/EDS analyses indicated that localized corrosion and $\mathrm{Cl}$ concentration occurred in the carbonaceous film-copper boundary. It was inferred that this was due to crevice corrosion caused by the gap between the carbonaceous film and copper surface and the galvanic corrosion between the carbonaceous film and copper;

- BTA mitigates localized corrosion at the anodic site by forming the $\mathrm{Cu}$-BTA complex in the carbonaceous film-copper boundary part. In addition, the formation of a $\mathrm{Cu}$-BTA complex in the copper part inhibits the formation of an oxygen-concentration cell. Consequently, BTA suppresses localized corrosion caused by the carbonaceous film.

Supplementary Materials: The following are available online at https: / www.mdpi.com/article / 10.3390/ma14112722/s1, Figure S1: Schematic images of three parts (carbonaceous part, coppercarbonaceous film boundary part, and copper part) of specimen 2. Figure S2: Cross-sectional EPMA images near pitting corrosion of copper pipe for sprinkler used for 11 years; (a) EPMA image $(1000 \times)$, (b) EPMA mapping data. Figure S3: Cu LMM X-ray induced spectra and deconvoluted results at the surface of copper after 24-hour immersion in synthetic tap water at $25^{\circ} \mathrm{C}$ based on the presence and absence of BTA.

Author Contributions: Conceptualization, Y.-H.L.; methodology, Y.-H.L., M.-S.H. and S.-J.K.; validation, M.-S.H., S.-J.K. and J.-G.K.; formal analysis, Y.-H.L.; investigation, Y.-H.L.; resources, M.-S.H.; data curation, Y.-H.L., M.-S.H. and S.-J.K.; writing—original draft preparation, Y.-H.L.; writingreview and editing, Y.-H.L., M.-S.H. and S.-J.K.; visualization, Y.-H.L.; supervision, J.-G.K.; project administration, J.-G.K.; funding acquisition, M.-S.H., S.-J.K. and J.-G.K. All authors have read and agreed to the published version of the manuscript.

Funding: This research was supported by the program for fostering next-generation researchers in engineering of National Research Foundation of Korea (NRF) funded by the Ministry of Science and ICT (2017H1D8A2031628). This work was also supported by an NRF grant funded by the Korean Government (NRF-2020-Research Staff Program) (NRF-2020R1I1A1A01074866).

Institutional Review Board Statement: Not applicable.

Informed Consent Statement: Not applicable.

Data Availability Statement: Not applicable. 
Acknowledgments: This research was supported by the Korea Land and Housing Corporation.

Conflicts of Interest: The authors declare no conflict of interest.

\section{References}

1. Suh, S.H.; Suh, Y.; Yoon, H.G.; Oh, J.H.; Kim, Y.; Jung, K.; Kwon, H. Analysis of pitting corrosion failure of copper tubes in an apartment fire sprinkler system. Eng. Fail. Anal. 2016, 64, 111-125. [CrossRef]

2. Cornwell, F.; Wildsmith, G.; Gilbert, P. Pitting corrosion in copper tubes in cold water service. Br. Corros. J. 1973, 8, 202-209. [CrossRef]

3. Lytle, D.A.; Nadagouda, M.N. A comprehensive investigation of copper pitting corrosion in a drinking water distribution system. Corros. Sci. 2010, 52, 1927-1938. [CrossRef]

4. El Warraky, A.; El Shayeb, H.; Sherif, E. Pitting corrosion of copper in chloride solutions. Anti Corros. Methods Mater. 2004, 51, 52-61. [CrossRef]

5. Lytle, D.A.; Schock, M.R. Pitting corrosion of copper in waters with high pH and low alkalinity. J. Am. Water Work. Assoc. 2008, 100, 115-129. [CrossRef]

6. Burleigh, T.D.; Gierke, C.G.; Fredj, N.; Boston, P.J. Copper tube pitting in Santa Fe municipal water caused by microbial induced corrosion. Materials 2014, 7, 4321-4334. [CrossRef] [PubMed]

7. Finšgar, M.; Milošev, I. Inhibition of copper corrosion by 1, 2, 3-benzotriazole: A review. Corros. Sci. 2010, 52, 2737-2749. [CrossRef]

8. Fateh, A.; Aliofkhazraei, M.; Rezvanian, A. Review of corrosive environments for copper and its corrosion inhibitors. Arab. J. Chem. 2020, 13, 481-544. [CrossRef]

9. Kim, Y.-S.; Kim, J.-G. Electrochemical and quantum chemical studies of 1, 2, 3-benzotriazole as inhibitor for copper and steel in simulated tap water. Mater. Trans. 2017, 58, 76-84. [CrossRef]

10. Walker, R. Triazole, benzotriazole and naphthotriazole as corrosion inhibitors for copper. Corrosion 1975, 31, 97-100. [CrossRef]

11. Hobbins, N.; Roberts, R. An ellipsometric study of thin films formed on copper by aqueous benzotriazole and benzimidazole. Surf. Technol. 1979, 9, 235-239. [CrossRef]

12. Yu, P.; Liao, D.-M.; Luo, Y.-B.; Chen, Z.-G. Studies of benzotriazole and tolytriazole as inhibitors for copper corrosion in deionized water. Corrosion 2003, 59, 314-318. [CrossRef]

13. Ross, T.; Berry, M. Benzotriazole as an inhibitor of the corrosion of $\mathrm{Cu}$ in flowing $\mathrm{H}^{*} 12^{*} \mathrm{sSO}^{*} 14^{*}$ s. Corros. Sci. 1971, 11, 273-274. [CrossRef]

14. Kosec, T.; Milošev, I.; Pihlar, B. Benzotriazole as an inhibitor of brass corrosion in chloride solution. Appl. Surf. Sci. 2007, 253, 8863-8873. [CrossRef]

15. Zhao, H.; Xu, Y.; Chen, C.; Chen, Y.; Liu, Y.; Yang, Z. New aspects of copper corrosion in a neutral NaCl solution in the presence of benzotriazole. Corrosion 2018, 74, 613-622. [CrossRef]

16. Khan, P.F.; Shanthi, V.; Babu, R.K.; Muralidharan, S.; Barik, R.C. Effect of benzotriazole on corrosion inhibition of copper under flow conditions. J. Environ. Chem. Eng. 2015, 3, 10-19. [CrossRef]

17. Oliphant, R. Causes of Copper Corrosion in Plumbing Systems; Foundation for Water Research: Buckinghamshire, UK, 2003.

18. Iyasu, T.; Kuratani, M.; Ikeda, I.; Tanaka, N.; Yamada, Y.; Sakurada, O. A Study of Water Treatment Chemical Effects on Type I" Pitting Corrosion of Copper Tubes. Mater. Sci. Appl. 2020, 11, 494. [CrossRef]

19. CEN. 1057: 2006 Copper and Copper Alloys-Seamleess, Round Copper Tubes for Water and Gas in Sanitary and Heating Applications; European Committee for Standardization: Brussels, Belgium, 2006.

20. Lee, J.-B.; Jung, H. Investigation on Causes of Pitting Corrosion in Sprinkler Copper Tubes. Corros. Sci. Technol. 2014, 13, 6-14. [CrossRef]

21. ASTM. B88: Standard Specification for Seamless Copper Water Tube; ASTM: West Conshohocken, PA, USA, 2013.

22. Davis, J.R. Copper and Copper Alloys; ASM International: Ohio, OH, USA, 2001.

23. Hong, M.-S.; Park, Y.; Kim, J.G.; Kim, K. Effect of incorporating MoS2 in organic coatings on the corrosion resistance of 316L stainless steel in a $3.5 \% \mathrm{NaCl}$ solution. Coatings 2019, 9, 45. [CrossRef]

24. Bi, H.; Burstein, G.; Rodriguez, B.; Kawaley, G. Some aspects of the role of inhibitors in the corrosion of copper in tap water as observed by cyclic voltammetry. Corros. Sci. 2016, 102, 510-516. [CrossRef]

25. Kosec, T.; Merl, D.K.; Milošev, I. Impedance and XPS study of benzotriazole films formed on copper, copper-zinc alloys and zinc in chloride solution. Corros. Sci. 2008, 50, 1987-1997. [CrossRef]

26. Liu, W.; Wang, B.; Cui, C.; Zhang, Y.; Wang, L.; Wang, Z. The surface restructuring of copper oxides with mixed oxidation-states and their efficient CO oxidation properties. Mater. Lett. 2021, 289, 129378. [CrossRef]

27. Lee, W.-J.; Lee, Y.-S.; Rha, S.-K.; Lee, Y.-J.; Lim, K.-Y.; Chung, Y.-D.; Whang, C.-N. Adhesion and interface chemical reactions of $\mathrm{Cu} /$ polyimide and Cu/TiN by XPS. Appl. Surf. Sci. 2003, 205, 128-136. [CrossRef]

28. McIntyre, N.; Sunder, S.; Shoesmith, D.; Stanchell, F. Chemical information from XPS-applications to the analysis of electrode surfaces. J. Vac. Sci. Technol. 1981, 18, 714-721. [CrossRef]

29. Shim, J.J.; Kim, J.G. Copper corrosion in potable water distribution systems: Influence of copper products on the corrosion behavior. Mater. Lett. 2004, 58, 2002-2006. [CrossRef] 
30. Li, J.; Liu, Y.; Wang, T.; Lu, X. Chemical effects on the tribological behavior during copper chemical mechanical planarization. Mater. Chem. Phys. 2015, 153, 48-53. [CrossRef]

31. Vasquez, R. CuO by XPS. Surf. Sci. Spectra 1998, 5, 262-266. [CrossRef]

32. Chen, Z.; Huang, L.; Zhang, G.; Qiu, Y.; Guo, X. Benzotriazole as a volatile corrosion inhibitor during the early stage of copper corrosion under adsorbed thin electrolyte layers. Corros. Sci. 2012, 65, 214-222. [CrossRef]

33. Vasquez, R.P. CuCl2 by XPS. Surf. Sci. Spectra 1993, 2, 160-164. [CrossRef]

34. Vasquez, R.P. CuCl by XPS. Surf. Sci. Spectra 1993, 2, 138-143. [CrossRef]

35. Raman, R.S.; Banerjee, P.C.; Lobo, D.E.; Gullapalli, H.; Sumandasa, M.; Kumar, A.; Choudhary, L.; Tkacz, R.; Ajayan, P.M.; Majumder, M. Protecting copper from electrochemical degradation by graphene coating. Carbon 2012, 50, 4040-4045. [CrossRef]

36. Zhang, R.; Wang, L.; Shi, W. Variable corrosion behavior of a thick amorphous carbon coating in NaCl solution. Rsc Adv. 2015, 5, 95750-95763. [CrossRef]

37. Cho, B.-J.; Shima, S.; Hamada, S.; Park, J.-G. Investigation of $\mathrm{Cu}-\mathrm{BTA}$ complex formation during $\mathrm{Cu}$ chemical mechanical planarization process. Appl. Surf. Sci. 2016, 384, 505-510. [CrossRef]

38. Hong, M.-S.; Kim, S.-H.; Im, S.-Y.; Kim, J.-G. Effect of ascorbic acid on the pitting resistance of 316L stainless steel in synthetic tap water. Met. Mater. Int. 2016, 22, 621-629. [CrossRef]

39. Liao, X.; Cao, F.; Zheng, L.; Liu, W.; Chen, A.; Zhang, J.; Cao, C. Corrosion behaviour of copper under chloride-containing thin electrolyte layer. Corros. Sci. 2011, 53, 3289-3298. [CrossRef]

40. Jones, D.A. Principles and Prevention of Corrosion; Macmillan: New York, NY, USA, 1992.

41. Rosenfeld, I.; Marshakov, I. Mechanism of crevice corrosion. Corrosion 1964, 20, 115t-125t. [CrossRef]

42. Modestov, A.; Zhou, G.-D.; Wu, Y.-P.; Notoya, T.; Schweinsberg, D. A study of the electrochemical formation of Cu (I)-BTA films on copper electrodes and the mechanism of copper corrosion inhibition in aqueous chloride/benzotriazole solutions. Corros. Sci. 1994, 36, 1931-1946. [CrossRef] 